\title{
Characterization of yeast deoxyhypusine synthase: PKC- dependent phosphorylation in vitro and functional domain identification
}

\author{
Kee Ryeon Kang ${ }^{1,3}$ and Soo II Chung ${ }^{2}$ \\ ${ }^{1}$ Department of Biochemistry and Gyeongsang Institute of \\ Cancer Research, Gyeongsang National University College of \\ Medicine, Chinju 660-280, Korea \\ ${ }^{2}$ Mogam Biotechnology Research Institute, Yongin 449-910, Korea \\ ${ }^{3}$ Corresponding author: Tel, 82-591-751-8730; \\ Fax, 82-591-759-8005; E-mail, krkang@gshp.gsnu.ac.kr
}

Accepted 3 December 1999

Abbreviations: PKC, protein kinase C; elF-5A, eukaryotic initiation factor 5A; PMA, phorbol 12-myristate 13-acetate

\begin{abstract}
The biosynthesis of hypusine [ $\mathrm{N}^{\varepsilon}$-(4-amino-2-hydroxybutyl)-lysine] occurs in the elF-5A precursor protein through two step posttranslational modification involving deoxyhypusine synthase which catalyzes transfer of the butylamine moiety of spermidine to the $\varepsilon$-amino group of a designated lysine residue and subsequent hydroxylation of this intermediate. This enzyme is exclusively required for cell viability and growth of yeast (Park, M.H. et al., J. Biol. Chem. 273: 1677-1683, 1998). In an effort to understand structure-function relationship of deoxyhypusine synthase, posttranslational modification(s) of the enzyme by protein kinases were carried out for a possible cellular modulation of this enzyme. And also twelve deletion mutants were constructed, expressed in $E$. coli system, and enzyme activities were examined. The results showed that deoxyhypusine synthase was phosphorylated by PKC in vitro but not by p56 ${ }^{\text {lck }}$ and $p 60^{c-s r c}$. Treatment with PMA specifically increased the relative phosphorylation of the enzyme supporting PKC was involved. Phosphoamino acid analysis of this enzyme revealed that deoxyhypusine synthase is mostly phosphorylated on serine residue and weakly on threonine. Removal of Met $^{1}-$ Glu $^{10}$ $\left(\Delta\right.$ Met $^{1}-$ Glu $\left.^{10}\right)$ residues from amino terminal showed no effect on the catalytic activity but further deletion $\left(\Delta\right.$ Met $^{1}-$ Ser $\left.^{20}\right)$ caused loss of enzyme activity. The enzyme with internal deletion, $\Delta$ GIn $^{197}$-Asn ${ }^{212}$ (residues not present in the human enzyme) was found to be inactive. Removal of 5 residues from carboxyl terminal, $\Delta \mathrm{Lys}^{383}$-Asn ${ }^{387}$, retained only slight activity.
\end{abstract}

These results suggested that deoxyhypusine synthase is substrate for PKC dependent phosphorylation and requires most of the polypeptide chains for enzyme activity except the first 15 residues of $\mathrm{N}$-terminal despite of $\mathrm{N}$ - and $\mathrm{C}$-terminal residues of the enzyme consist of variable regions.

Keywords: deoxyhypusine synthase, PKC, phosphorylation, deletion mutation

\section{Introduction}

The biosynthesis of hypusine $\left[\mathrm{N}^{\varepsilon}\right.$-(4-amino-2-hydroxybutyl)-lysine] occurs exclusively in one cellular protein, the precursor of eukaryotic translation initiation factor $5 \mathrm{~A}$ (elF-5A) through a unique two-step posttranslational modification (Park et al., 1993a; Park et al., 1993b). In the first step, deoxyhypusine synthase catalyzes NADdependent transfer of the butylamine moiety of the polyamine spermidine to the $\varepsilon$-amino group of a specific lysine residue of elF-5A precursor (Lys ${ }^{51}$ in the yeast protein) to form a deoxyhypusine [ $\mathrm{N}^{\varepsilon}$-(4-aminobutyl) lysine] residue (Park et al., 1982; Wolff et al., 1995). Subsequent hydroxylation of this intermediate by deoxyhypusine hydroxylase completes hypusine conformation and elF5A maturation (Park et al., 1993a; Park et al., 1993b).

Several lines of evidence support the fact that elF-5A and its hypusine modification play a pivotal role in eukaryotic cell proliferation (Park et al., 1993a; Park et al., 1993b). In the yeast Saccharomyces cerevisiae, inactivation of elF-5A gene (Schnier et al., 1991; Wöhl et al., 1993) or of the deoxyhypusine synthase gene (Park et al., 1998) results in the loss of cell viability. In mammalian cells, inhibitors of either deoxyhypusine synthase (Park et al., 1994) or deoxyhypusine hydroxylase (Hanauske-Abel et al., 1994) exert antiproliferative effects. The arrest in cell proliferation by inhibitors of polyamine biosynthetic enzymes has been attributed to depletion of elF-5A following depletion of spermidine (Byers et al., 1992).

Deoxyhypusine synthase has been purified from rat testis (Wolff et al., 1995), Neurospora crassa (Tao and Chen, 1995a), HeLa cells (Klier et al., 1995), and yeast (Sasaki et al., 1996). Human (Joe et al., 1995; Tao and Chen, 1996) and N. crassa (Tao and Chen, 1995b) cDNAs for the enzyme have been cloned, and its gene has been identified (Kang et al., 1995; Klier et al., 1995; Tao and Chen, 1995b) and cloned (Sasaki et al., 1996) 
in yeast. The amino acid sequence of deoxyhypusine synthase is highly conserved and the native enzymes consist of tetramers of four identical subunits of 40 to 43 $\mathrm{kDa}$, depending on the species.

Protein synthesis consumes a significant proportion of the available energy of eukaryotic cells. Rates of protein synthesis are regulated, thereby integrating the translation process with other metabolic pathways of the cell. In many cases, translation rates change within minutes of the inductive events and are readily reversed, suggesting that the regulatory mechanisms involve rapid changes in the specific activities of the protein synthesis machinery rather than changes in the cellular concentration of any of its components. Covalent modification of proteins by phosphorylation is well known to control many metabolic pathways and may likewise regulate translation rates (Hershey, 1989). Initiation stage, especially in translational machinery, is regarded as the most commonly observed target for physiological control. Several of the initiation factors are phosphoproteins but the clearest links between phosphorylation and the regulation of translation concern the factors elF-2 and elF-4E (Rhoads, 1993; Pain, 1996).

elF-5A, the unique hypusine-containing initiation factor, is implicated in the final step of the initiation phase of protein synthesis (Benne et al., 1978). Besides hypusine modification, elF-5A in yeast is phosphorylated on serine. Therefore elF-5A undergoes two posttranslational modifications, hypusination and phosphorylation, where the activity of the factor is dependent on the first but is not influenced in vitro by the second. However, hypusine formation in elF-5A is not reversed when rates or specificity of protein synthesis is altered (Gordon et al., 1987). Therefore another reversible modification for the regulation of elF-5A activity may be implicated. Deoxyhypusine synthase, the first enzyme involved in hypusination, could be the primary target of the regulation of the factor.

We undertook a study to provide insight into the minimal structural requirements for the activity of yeast deoxyhypusine synthase through deletion mutation. Our data as well as those of Abid et al. (1997), reported while this work was in progress, indicate that even though the $\mathrm{N}$ - and $\mathrm{C}$-terminal residues of the yeast deoxyhypusine synthase are outside the highly conserved regions, they play an important role in the activity of the yeast enzyme. In addition, study of internal deletion mutation, designed on the basis of a comparison of the amino acid sequences of the yeast and human deoxyhypusine synthases, provide insight into the structurefunction relationship of the enzyme. Recently, we have identified that deoxyhypusine synthase essential for irreversible hypusine formation was phosphorylated by PKC in vitro. In this study, we report phosphorylation modification of yeast recombinant deoxyhypusine synthase and structural requirement of the enzyme through sequential deletion of non-conserved sequence segment of the deoxyhypusine synthase.

\section{Materials and Methods}

\section{Materials}

$\left[1,8-{ }^{3} \mathrm{H}\right]$ Spermidine $\cdot \mathrm{HCl}(15 \mathrm{Ci} / \mathrm{mmol})$ and $\left[\gamma^{-32} \mathrm{P}\right] \mathrm{ATP}$ $(5,000 \mathrm{Ci} / \mathrm{mmol})$ were purchased from New England Nuclear. Oligonucleotide primers were synthesized by Genotech, Korea. pET-11a expression vector and the host Escherichia coli B strain BL21(DE3) were from Novagen; Taq polymerase, T4 DNA ligase, restriction enzymes, casein kinase II (CKII), and PKC from Boehringer mannheim; $\mathrm{p} 60^{c-s r c}$ and $\mathrm{p} 56^{\text {lck }}$ from Upstate Biotechnology; cellulose thin-layer chromatography (TLC) plates (without fluorescent indicator) from Merck. PMA was obtained from Sigma, and other chemicals were purchased as described in the text. Yeast elF-5A precursor proteins expressed in $E$. coli were purified from E. coli lysates after overexpression of the yeast elF-5A cDNAs, are described previously (Kang et al., 1995).

\section{In vitro phosphorylation}

The phosphorylation reaction of yeast recombinant deoxyhypusine synthase was carried out at $37^{\circ} \mathrm{C}$ for 30 min with various kinases such as CKII, PKC, p56 ${ }^{\text {lck }}$, and p60 ${ }^{c-s r c}$, in a total reaction volume of $25 \mu \mathrm{l}$ containing kinase buffer $(20 \mathrm{mM}$ Tris, $\mathrm{pH}$ 7.5, $10 \mathrm{mM}$ magnesium acetate, $0.4 \mathrm{mM} \mathrm{CaCl}_{2}$, and $1 \mathrm{mM}$ dithiothreitol) in the presence of $\left[\gamma^{32} \mathrm{P}\right]$ ATP. For time course phosphorylation, yeast deoxyhypusine synthase was reacted for 1,10 , 30 , and $60 \mathrm{~min}$. In the case of PMA treatment, up to 10 $\mu \mathrm{M}$ of PMA were used to stimulate the phosphorylation reaction. The reaction was terminated by mixing with SDS sample buffer, boiled, and run on a $10 \%$ SDSpolyacrylamide gel. The gel was stained in $0.125 \%$ Coomassie blue and destained in a solution of $40 \%$ methanol/10\% glacial acetic acid. After drying, the gel was exposed to a film to visualize radiolabeled proteins.

\section{Phosphoamino acid analysis}

To analyze phosphoamino acid of yeast deoxyhypusine synthase, purified protein was incubated with PKC in the presence of $\left[\gamma^{32} \mathrm{P}\right]$ ATP. Phosphorylated deoxyhypusine synthase was separated by electrophoresis on a $10 \%$ SDS-polyacrylamide gel and transferred to Immobilon (Millipore) (Kamps and Sefton, 1989; Duclos et al., 1991). The Immobilon membrane was wet in methanol for 10 min and then incubated in transfer buffer (193 mM glycine, $25 \mathrm{mM}$ Tris/base, $0.1 \%$ SDS, and $20 \%$ methanol) for 30 min. Transfer to the membrane was carried out using transfer buffer at $150 \mathrm{~mA}$ for $2 \mathrm{~h}$. Proteins bound to Immobilon were visualized by staining with India ink for $1 \mathrm{~h}$. The membrane was rinsed with several changes of 
deionized water, and the rinsed membrane was then dried and subjected to autoradiography. ${ }^{32} \mathrm{P}$-labeled deoxyhypusine synthase band was excised, transferred to screwcap microfuge tube, and hydrolyzed at $110^{\circ} \mathrm{C}$ for 2 $\mathrm{h}$ in $6 \mathrm{~N} \mathrm{HCl}$ under nitrogen gas. After hydrolysis, the tubes were centrifuged for $5 \mathrm{~min}$ and the supernatant was transferred to a new tube. The aqueous hydrolysate was dried in a speedvac concentrator, dissolved in $\mathrm{pH}$ 1.9 buffer (acetic acid/formic acid/water, $78: 25: 897$, v/ $\mathrm{v} / \mathrm{v}$ ) containing $3 \mu \mathrm{g}$ each of phosphoserine, phosphothreonine, and phosphotyrosine. Two-dimensional electrophoresis/chromatography was performed on cellulose TLC plate. Electrophoresis was done at $\mathrm{pH} 1.9$ buffer at 2.5 $\mathrm{kV}$ for $25 \mathrm{~min}$ (first dimension) followed by ascending chromatography in isobutyric acid/0.5 M ammonium hydroxide $(5: 3, v / v)$ (second dimension). Autoradiography was performed at $-70^{\circ} \mathrm{C}$ using intensifying screen. Standards were visualized by ninhydrin staining.

\section{In vitro assay of deoxyhypusine synthesis activity}

The enzyme activity was measured as described previously (Kang et al., 1995). A typical reaction mixture contained, in a total volume of $20 \mu \mathrm{l}, 0.2 \mathrm{M}$ glycine$\mathrm{NaOH}$ buffer, $\mathrm{pH} 9.5,1 \mathrm{mM}$ dithiothreitol, $5 \mu \mathrm{g}$ of bovine serum albumin, $1 \mathrm{mM}$ NAD, $7-9 \mu \mathrm{M}(2-5 \mu \mathrm{Ci})\left[1,8-{ }^{3} \mathrm{H}\right]$ spermidine, $10 \mu \mathrm{M}$ human or yeast elF-5A precursor protein, and wild type or mutant enzyme. Incubations were at $37^{\circ} \mathrm{C}$ for $60 \mathrm{~min}$. After trichloroacetic acid precipitation, the precipitate was washed three times with $10 \%$ trichloroacetic acid containing putrescine, spermidine, and spermine (1 $\mathrm{mM}$ each), dissolved in 0.4 $\mathrm{ml}$ of $6 \mathrm{~N} \mathrm{HCl}$ and hydrolyzed at $105^{\circ} \mathrm{C}$ for $16 \mathrm{~h}$. The $\left[{ }^{3} \mathrm{H}\right]$ deoxyhypusine formed was measured after its separation from other components of the acid hydrolyzed protein fraction by ion exchange chromatography as described previously (Wolff et al., 1990). One unit of activity is defined as the amount of enzyme catalyzing the formation of $1 \mathrm{pmol} \mathrm{h}^{-1}$ of deoxyhypusine.

\section{Construction of deletion recombinant subclones of yeast deoxyhypusine synthase cDNA and their expression in $E$. coli}

On the basis of the nucleotide sequence of the full length yeast deoxyhypusine synthase, the mutant subclones with a truncated $\mathrm{N}$-terminus or a truncated $\mathrm{C}$ terminus, were generated using synthetic oligonucleotide primers (Table 1). A mutant CDNA with an internal deletion was constructed by a two-step PCR procedure. In the first step, DHS M1 and DHS M2 cDNAs were generated in two separate reactions (Table 2). The PCR products of the expected size were isolated from an agarose gel, and the mixture of the two amplified fragments was used as template in the second PCR step to construct DHS M3. These mutants were cloned in the pET-11a vector and confirmed by sequencing.
Table 1. Nucleotide sequences of primers used in PCRs

\begin{tabular}{|c|c|}
\hline \multicolumn{2}{|l|}{ Forward primers } \\
\hline Primer N0 (1-8) (for WT) & ettccagtatgctcatATG TCC GAT ATC AAC GAA AAA CTC \\
\hline Primer N1 (6-12) & ettccagtatgctcatATG GAA AAA CTC CCA GAG TTA CTA \\
\hline Primer N2 (1.1-17) & cttccagtatgctcatATG TTA CTA CAA GAC GCT GTC TTG \\
\hline Primer N3 (16-22) & cttccagtatgetcatATG GTC TTG AAA GCA TCT GTT CCT \\
\hline Primer N4 (21-27) & ettccagtatgctcatATG GTT CCT ATT CCA GAT GAC TTC \\
\hline Primer N5 (26-32) & cttccagtatgctcatATG GAC TTC GTT AAG GTT CAA GGT \\
\hline Primer M1 (190-196, 213-221) & $\begin{array}{l}\text { TTG GAT AAG ATG TTG GAA GAA CAA GAC GTG GAT } \\
\text { TCA CCA ATC TGG ACC }\end{array}$ \\
\hline \multicolumn{2}{|l|}{ Reverse primers } \\
\hline Primer CO (387-381) (for WT) & cttccagtatggatcc TCA ATT CTT AAC TTT TTT GAT TGG \\
\hline Primer C1 (382-376) & ettccagtatggatec TCA GAT TGG TTT ACC ACT GGC AAA \\
\hline Primer C2 (377-371) & cttccagtatggatccTCA GGC AAA GGT AGC AGC AAC AAT \\
\hline Primer C3 (372-366) & cttccagtatggatecTCA AAC AAT CAA TGG AAG AAC AGT \\
\hline Primer C4 (367-361) & cttccagtatggatccTCA AAC AGT GGT GAC ATC AGC AAA \\
\hline Primer M2 (219-213, 196-188) & $\begin{array}{l}\text { GAT TGG TGG ATC CAC GTC TTG TTC TTC CAA CAT } \\
\text { CTT ATC CAA AAT TGG }\end{array}$ \\
\hline
\end{tabular}

The numbers in parentheses indicate the amino acid residue numbers of the coding or complementary sequences of yeast deoxyhypusine synthase; these sequences are denoted in upper-case letters. The Nde I sites for the forward primers, and the $\mathrm{Bam} \mathrm{HI}$ sites for the reverse primers are underlind.

Table 2. Construction of full-length and deleted deoxyhypusine synthase cDNAs by PCR and the activities of the recombinant proteins

\begin{tabular}{|c|c|c|c|}
\hline $\begin{array}{l}\text { Recombinant } \\
\text { subclones }\end{array}$ & $\begin{array}{l}\text { Recombinant } \\
\text { protein }\end{array}$ & Coding region & Activity \\
\hline \multirow[t]{3}{*}{ Full-length clone } & WT & & +t+t \\
\hline & - N1 & & +t++ \\
\hline & $\mathrm{N} 2$ & & ++++ \\
\hline \multirow[t]{5}{*}{5 deletion clones } & $\mathrm{N} 3$ & & + \\
\hline & N4 & & - \\
\hline & L N5 & & - \\
\hline & {$[\mathrm{C} 1$} & & + \\
\hline & $\mathrm{C} 2$ & & - \\
\hline \multirow[t]{3}{*}{3 deletion clones } & $\mathrm{C} 3$ & & - \\
\hline & $L_{C}$ & & - \\
\hline & $\Gamma \mathrm{M} 1$ & & n.d. \\
\hline \multirow[t]{2}{*}{$\begin{array}{l}\text { Internal deletion } \\
\text { clone }\end{array}$} & M2 & & n.d. \\
\hline & M3 & & - \\
\hline
\end{tabular}

In the schematic representation, yeast coding sequences are black boxes, and the deleted regions are white boxes. In the case 5'-terminal deletions, methionine was artificially introduced as the $\mathrm{NH}_{2}$-terminal amino acid. The numbers indicate the amino acid residue number in the yeast coding sequence. n.d., not determined; $\mathrm{M}$, mutant; $\mathrm{WT}$, wild type; $\mathrm{N}, \mathrm{NH}_{2}$-terminus; $\mathrm{C}, \mathrm{COOH}$-terminus.

Expression of the deletion mutations of yeast deoxy- 


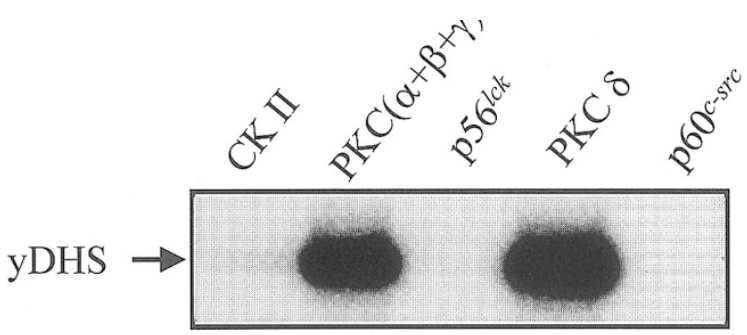

Figure 1. Phosphorylation of yeast recombinant deoxyhypusine synthase (DHS) by various kinases. Purified yeast recombinant deoxyhypusine synthase was incubated with different kinases; casein kinase II (lane 1), protein kinase $C \alpha+\beta+\gamma$ mixture (lane 2), p56 $6^{\text {lck }}$ (lane 3 ), protein kinase $C \delta$ (lane 4$)$, and $p 60^{c-s c}($ lane 5$)$, respectively, in the presence of $\left[\gamma^{-32}\right.$ P]ATP. After drying of the SDS-polyacrylamide gel, autoradiography was performed with intensifying screen at $-70^{\circ} \mathrm{C}$. Phosphorylated DHS with molecular mass of $44 \mathrm{kD}$ was indicated by arrow. yDHS denotes yeast deoxyhypusine synthase.

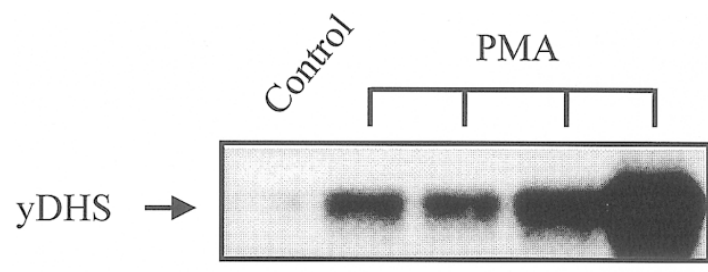

$$
\begin{array}{lllllll}
\text { Conc.: } & 0 & 0.1 & 0.25 & 1 & 10 & \mu \mathrm{M}
\end{array}
$$

Figure 2. PMA (phorbol 12-myristate 13-acetate) stimulates the phophorylation of yeast recombinant deoxyhypusine synthase by PKC in vitro. Deoxyhypusine synthase was incubated with $\left[\gamma^{32}\right.$ P]ATP and PKC in the absence (lane 1), or presence of $0.1 \mu \mathrm{M}$ (lane 2), $0.25 \mu \mathrm{M}$ (lane 3), $1 \mu \mathrm{M}$ (lane 4), and $10 \mu \mathrm{M}$ (lane 5) PMA, respectively. Phosphorylated DHS was visualized by SDS-PAGE followed by autoradiography. Conc., concentration.

hypusine synthase in $E$. coli and purification of the altered recombinant proteins were carried out as described earlier (Kang et al., 1995).

\section{Results}

Yeast deoxyhypusine synthase contains multiple potential phosphorylation sequence motifs for CKII, PKC, and tyrosine kinases. This suggests that yeast deoxyhypusine synthase could be phosphorylated on tyrosine as well as serine and threonine. To examine whether these kinases are involved in deoxyhypusine synthase phosphorylation, purified yeast recombinant deoxyhypusine synthase (Kang, et al., 1995) was incubated with different kinases. Deoxyhypusine synthase was phosphorylated by PKC isoforms, $\alpha+\beta+\gamma$ mixure or $\delta$, in vitro (Figure 1, lane 2 and 4). Although CKII, a typical Ser/Thr kinase, was able to phosphorylate yeast enzyme protein, but the level of phosphorylation was significantly lower than that of PKC (Figure 1, lane 1). Other tyrosine kinases such as $\mathrm{p} 56^{\text {lck }}$ and $\mathrm{p} 60^{c-s r c}$, however, were not involved in the phosphorylation reaction (Figure 1, lane 3 and 5).

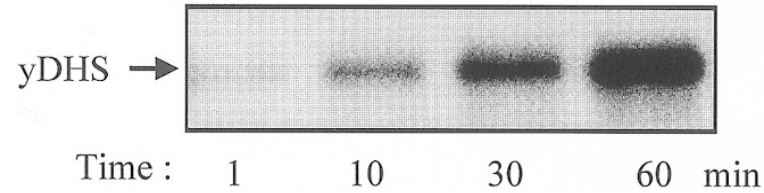

Figure 3. Time-dependent phosphorylation of yeast recombinant deoxyhypusine synthase by PKC. The kinase reaction of yeast enzyme was carried out at $37^{\circ} \mathrm{C}$ for various times in a total reaction volume of $25 \mu \mathrm{l}$ containing kinase buffer. The reaction was terminated by mixing with SDS sample buffer, boiled, and run on a $10 \%$ SDS-PAGE. After staining with Coomassie blue, the gel was dried and exposed to a X-ray film.

PMA, tumor promoter, stimulates the phosphorylation of yeast deoxyhypusine synthase by PKC in vitro. As shown in Figure 2, the amount of ${ }^{32} \mathrm{P}$-incorporation into deoxyhypusine synthase started to increase at $0.1 \mu \mathrm{M}$ PMA (5-folds), and $10 \mu \mathrm{M}$ treatment of this tumor promoter increased deoxyhypusine synthase 15 -folds. This result reveals that deoxyhypusine synthase was stimulated by $0.1 \mu \mathrm{M}$ PMA and increased up to $10 \mu \mathrm{M}$ treatment. Additionally, the maximal stimulatory effect with PMA was within $1 \mathrm{~h}$ (data not shown). Figure 3 shows that yeast deoxyhypusine synthase was phosphorylated in a time-dependent manner by PKC in vitro. Phosphoamino acid analysis of yeast deoxyhypusine synthase phosphorylated by PKC revealed that this enzyme was phosphorylated mainly on serine, and trace amount of ${ }^{32} \mathrm{P}$-incorporation into threonine was visible (Figure 4). But no detectable spot on tyrosine in

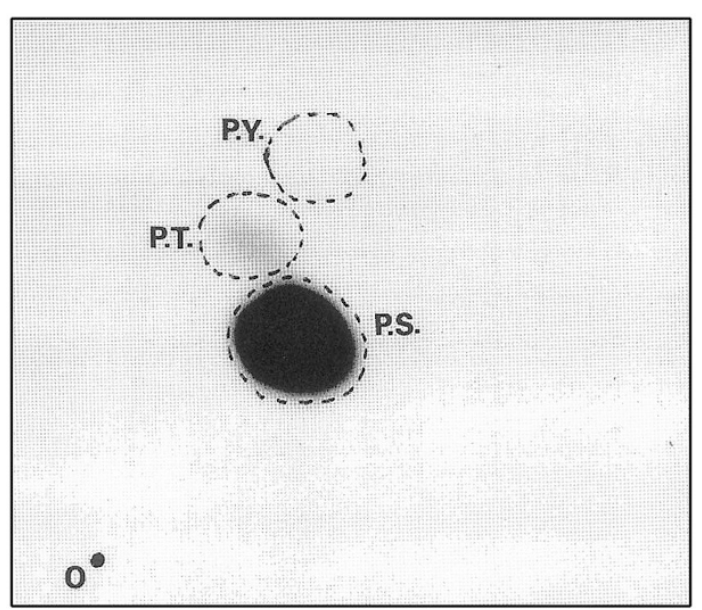

Figure 4. Phosphoamino acid analysis of yeast DHS phosphorylated by PKC. ${ }^{32}$ P-labeled DHS by PKC was separated by SDS-PAGE, and tranferred to Immobilon membrane. The membrane piece corresponding to DHS was hydrolyzed under vacuum in $6 \mathrm{~N} \mathrm{HCl}$ at $110^{\circ} \mathrm{C}$ for $2 \mathrm{~h}$, and dried in speedvac concentrator. Dried sample was subjected to electrophoresis at $\mathrm{pH} 1.9 \mathrm{in}$ acetic acid/formic acid/water (78:25:897, v/v/v) at $2.5 \mathrm{kV}$ for 25 min (first dimension) followed by ascending chromatography in isobutyric acid/0.5 M ammonium hydroxide $(5: 3)$ (second dimension). Autoradiography was performed for $5 \mathrm{~h}$ at $-70^{\circ} \mathrm{C}$. Standard phosphoamino acids were visualized by ninhydrin staining. P.S., P.T., and P.Y. denote phosphoserine, phosphothreonine, and phosphotyrosine, respectively, and $\mathrm{O}$ denotes origin for sample. 


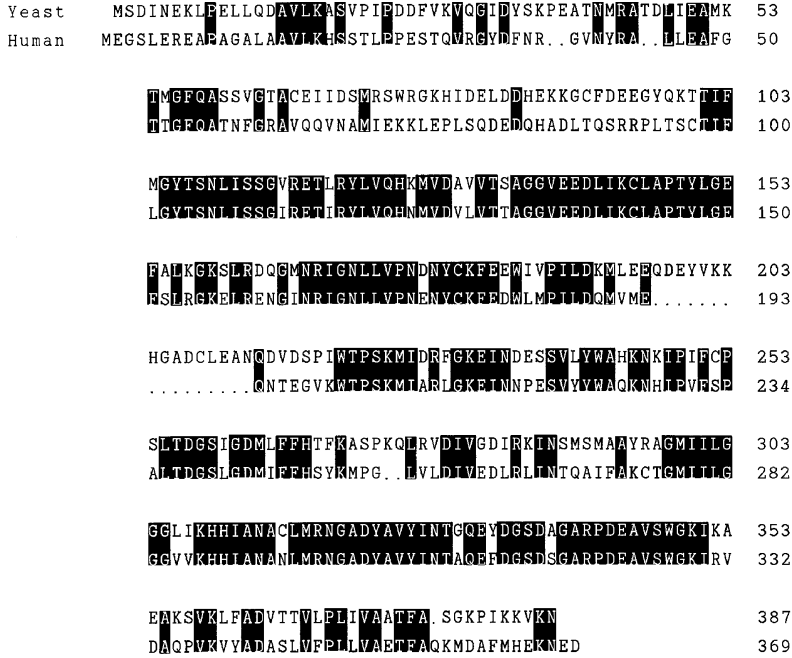

Figure 5. Comparison of amino acid sequences of yeast and human deoxyhypusine synthase. The amino acid sequences deduced from yeast cDNA are compared with that of human. To allow for maximal alignment of the yeast and human sequences, gaps have been introduced (.....). The amino acid residue numbers for the yeast and human sequences are indicated on the right. Identical amino acid residues are boxed (Joe et al., 1995).

TLC plate was identified. When the enzyme was tested for the possible alteration of deoxy hypusine synthase activity during the phosporylation processes by PKC, there was no observable changes in enzyme activity.

In order to assess the minimal structural requirements for the activity of the yeast deoxyhypusine synthase, we designed mutant clones with serial deletions from the $\mathrm{NH}_{2}$-terminus or from the $\mathrm{COOH}$-terminus. As shown in Table 2, lysates of E.coli cells overexpressing recombinant proteins with truncation of either 5 or 10 amino acids from the $\mathrm{N}$-terminus was found to display same enzyme activity with that of wild type enzyme. Deletion of 15 amino acids from the $\mathrm{N}$-terminus drastically reduced enzyme activity, and 20 amino acids or more deletion showed no enzyme activity. Only 10 amino acid deletion from the $\mathrm{C}$-terminus of the enzyme, however, exhibited no enzyme activity.

In an attempt to examine the basis of significant difference in the $K_{m}$ value for NAD for the yeast and human enzyme, a mutant clone was generated with deletion of internal 16 amino acids of the yeast sequence $\left(\mathrm{Gln}^{197}-\mathrm{Asn}^{212}\right.$, not present in the human enzyme) (Figure 5 and Table 2). E. coli lysate of the resultant mutant clone was isolated by Mono $Q$ ion-exchange column chromatography (data not shown), displayed no detectable enzyme activity (Table 2).

\section{Discussion}

Deoxyhypusine synthase is a bifunctional enzyme that catalyzes the NAD-dependent oxidative cleavage of spermidine and the subsequent transfer of an aminobutyl moiety to a specific lysine residue of the elF-5A precursor (Park et al., 1993a: Park et al., 1993b). We have identified and functionally expressed yeast deoxyhypusine synthase cDNA (Kang et al., 1995). The yeast recombinant deoxyhypusine synthase enzyme is a 387amino acid protein. This enzyme is a homotetramer consisting of $43 \mathrm{kDa}$ subunits in its native form. Deoxyhypusine synthase exhibits a remarkable substrate specificity in its recognition of a single lysine residue of the elF-5A precursor. elF-5A is highly conserved in a wide range of eukaryotic species, and the amino acid sequence identity is especially high in the region surrounding the lysine residue that undergoes modification to hypusine (Park et al., 1993a). Furthermore, a large portion of the substrate protein is required for recognition and modification by deoxyhypusine (Joe and Park, 1994).

Hypusine modification is essential for elF-5A activity; the modification is actually irreversible. However, elF-5A must be regulated reversibly because this protein is one of important translation initiation factors needed for synthesizing other cellular proteins. The most promising target for reversible regulation of elF-5A is deoxyhypusine synthase, the first enzyme involved in its hypusination. Recently, we have searched for the primary structure of yeast deoxyhypusine synthase, and found to have motifs for multiple potential phosphorylation modification. On the basis of this finding, yeast recombinant deoxyhypusine synthase was used for in vitro phosphorylation with various kinases such as CKII, PKC, p56 $6^{\text {lck }}$, and $p 60^{c-s r c}$. As results indicated that PKC is a powerful candidate for in vivo phosphorylation.

Protein kinase $\mathrm{C}$ denotes a family of isozymes that play a central role in signal transduction in eukaryotes. PKC is the major cellular receptor for the tumor-promoting phorbol esters, which activate PKC in a manner very similar to diacylglycerol (Zhang et al., 1995). Treatment with PMA specifically increased the relative phosphorylation of deoxyhypusine synthase in yeast and also in human (data not shown), supporting PKC was implicated in the control of this system. The data that yeast recombinant deoxyhypusine synthase was phosphorylated in a time-dependent manner by PKC may suggest that several PKC phosphorylation motifs in the deoxyhypusine synthase protein could exist and participate in an allosteric enhancement of phosporylation (Jung, et al., 1997). Although there were no previous report on the regulation of deoxyhypusine synthase by PKC-mediated phosphorylation in the cell, our findings of PKC catalyzed phosporylation of yeast deoxyhypusine synthase in vitro raises such possibility in vivo. However, we observed no direct evidence of close correlation between the phosphorylation state and the activity of deoxyhypusine synthase.

Our results of structural requirements for the activity of yeast recombinant deoxyhypusine synthase were con- 
sistent with those of Abid et al. (1997). Truncations of 20 $\mathrm{NH}_{2}$-terminal amino acids $\left(\mathrm{Met}^{1}-\mathrm{Ser}^{20}\right.$ ) or $10 \mathrm{COOH}$ terminal amino acids $\left(\mathrm{Ser}^{378}-\mathrm{Asn}^{387}\right.$ ) were devoid of enzymatic activity. These findings suggest that even though the $\mathrm{NH}_{2}$ - and $\mathrm{COOH}$-terminal residues of deoxyhypusine synthase are not highly conserved, these regions also contain amino acid sequences important for the proper conformation of the enzyme in monomeric unit stability and/or for tetramer formation necessary for binding substrates and for catalysis. The most striking difference between the primary structures of the yeast and human enzymes is no existence of a human counterpart matching $\mathrm{Gln}^{197}-\mathrm{Asn}^{212}$ in the yeast enzyme (Figure 5) (generated by the program GCG "BestFit" [Genetics Computer Group, Madison, WI]). Unexpectedly, a mutant protein with this internal 16-amino acid deleted yeast sequence displayed no enzyme activity. Since deletion of yeast sequence $\left(\mathrm{Gln}^{197}-\mathrm{Asn}^{212}\right)$ not present in the human enzyme did not result in a dramatic decrease in its $\mathrm{K}_{m}$ value for NAD, one cannot attribute the large differences in affinities toward NAD specifically to this region of the molecule. On the other hand, it is intriguing that this deletion have a significantly detrimental effect on the yeast enzyme activity. However, it could be possible that there is another alignment of the yeast deoxyhypusine synthase amino acid sequence from plant tobacco, human, yeast, $N$. crassa, and the archaebacterium $M$. Jannaschii (Ober and Hartmann, 1999) using different software ESPript analysis (Gouet et al., 1999). According to this result, GIn at 193 of the tobacco deoxyhypusine synthase is well conserved from archaebacterium to human in all species studied. Especially, GIn residue of the yeast deoxyhypusine synthase corresponding to $\mathrm{Gln}^{193}$ of the tobacco enzyme in sequence alignment is identical to $\mathrm{Gln}^{197}$ deleted in M3 mutant protein (Figure 5 and Table 2). Therefore, it remain to be elucidated whether the loss of activity in internal deletion clone of the yeast enzyme is due to absence of $\mathrm{Gln}^{197}$, highly conserved amino acid located in the mid portion of the enzyme.

\section{Acknowledgements}

We are grateful to So-Young Lee for assistance in the preparation of manuscript. This study was supported by the Basic Medical Research Fund (1997), Ministry of Education, Republic of Korea.

\section{References}

Abid, M. R., Ueda, K. and Miyazaki, M. (1997) Novel features of the functional site and expression of the yeast deoxyhypusine synthase. Biol. Signals 6: 157-165

Benne, R., Brown-Luedi, M. and Hershey, J. W. B. (1978) Purification and characterization of protein synthesis initiation factors elF-1, elF-4C, elF-4D, and elF-5 from rabbit reticulocytes. J. Biol. Chem. 253: 3070-3077

Byers, T. L., Ganem, B. and Pegg, A. E. (1992) Cytostasis induced in L1210 murine leukaemia cells by the S-adenosylL-methionine decarboxylase inhibitor 5'-([(Z)-4-amino-2-butenyl]methylamino)-5'-deoxyadenosine may be due to hypusine depletion. Biochem. J. 287: 717-724

Duclos, B., Marcandier, S. and Cozzone, A. J. (1991) Chemical properties and separation of phosphoamino acids by thinlayer chromatography and/or electrophoresis. Methods Enzymol. 201: 10-21

Gordon, E. D., Mora, R., Meredith, S. C. and Lindquist, S. L. (1987) Hypusine formation in eukaryotic initiation factor 4D is not reversed when rates or specificity of protein synthesis is altered. J. Biol. Chem. 262: 16590-16595

Gouet, P., Courcelle, E., Stuart, D. and Metoz, F. (1999) ESPript analysis of multiple sequence alignments in PostScript. Bioinformatics 15: 305-308

Hanauske-Abel, H. M., Park, M. H., Hanauske, A.-R., Popowicz, A. M., Lalande, M. and Folk, J. E. (1994) Inhibition of the G1-S transition of the cell cycle by inhibitors of deoxyhypusine hydroxylation. Biochim. Biophys. Acta 1221: 115-124

Hershey, J. W. B. (1989) Protein phosphorylation controls translation rates. J. Biol. Chem. 264: 20823-20826

Joe, Y. A. and Park, M. H. (1994) Structural features of the elF-5A precursor required for posttranslational synthesis of deoxyhypusine. J. Biol. Chem. 269: 25916-25921

Joe, Y. A., Wolff, E. C. and Park, M. H. (1995) Cloning and expression of human deoxyhypusine synthase cDNA. J. Biol. Chem. 270: 22386-22392

Jung, E. J., Kang, K. R. and Kang, Y.-S. (1997) Phosphorylation of chicken protein tyrosine phosphatase 1 by casein kinase II in vitro. Exp. Mol. Med. 29: 195-199

Kamps, M. P. and Sefton, B. M. (1989) Acid and base hydrolysis of phosphoproteins bound to immobilon facilitates analysis of phosphoamino acids in gel-fractionated proteins. Anal. Biochem. 176: 22-27

Kang, H. A., Schwelberger, H. G. and Hershey, J. W. B. (1993) Translation initiation factor elF-5A, the hypusinecontaining protein, is phosphorylated on serine in Saccharomyces cerevisiae. J. Biol. Chem. 268: 14750-14756

Kang, K. R., Wolff, E. C., Park, M. H., Folk, J. E. and Chung, S. I. (1995) Identification of YHR068w in Saccharomyces cerevisiae chromosome VIII as a gene for deoxyhypusine synthase. J. Biol. Chem. 270: 18408-18412

Klier, H., Csonga, R., Steinkasser, A., Wöhl, T., Lottspeich, F. and Eder, J. (1995) Purification and characterization of human deoxyhypusine synthase from HeLa cells. FEBS Lett. 364: 207-210

Ober, D. and Hartmann, T. (1999) Deoxyhypusine synthase from tobacco. J. Biol. Chem. 274: 32040-32047

Pain, V. M. (1996) Initiation of protein synthesis in eukaryotic cells. Eur. J. Biochem. 236: 747-771 
Park, M. H., Cooper, H. J. and Folk, J. E. (1982) The biosynthesis of protein-bound hypusine ( $\mathrm{N}^{\varepsilon}$-(4-amino-2-hydroxybutyl)lysine). J. Biol. Chem. 257: 7217-7222

Park, M. H., Joe, Y. A. and Kang, K. R. (1998) Deoxyhypusine synthase activity is essential for cell viability in the yeast Saccharomyces cerevisiae. J. Biol. Chem. 273: 1677-1683

Park, M. H., Wolff, E. C. and Folk, J. E. (1993a) Hypusine: its post-translational formation in eukaryotic initiation factor $5 \mathrm{~A}$ and its potential role in cellular regulation. Biofactors 4: 95-104

Park, M. H., Wolff, E. C. and Folk, J. E. (1993b) Is hypusine essential for eukaryotic cell proliferation? Trends Biochem. Sci. 18: $475-479$

Park, M. H., Wolff, E. C., Lee, Y. B. and Folk, J. E. (1994) Antiproliferative effects of inhibitors of deoxyhypusine synthase. J. Biol. Chem. 269: 27827-27832

Rhoads, R. E. (1993) Regulation of eukaryotic protein synthesis by initiation factors. J. Biol. Chem. 268: 3017-3020

Sasaki, K., Abid, M. R. and Miyazaki, M. (1996) Deoxyhypusine synthase gene is essential for cell viability in the yeast Saccharomyces cerevisiae. FEBS Lett. 384: 151-154

Schnier, J. (1991) Translation initiation factor 5A and its hypusine modification are essential for cell viability in the yeast Saccharomyces cerevisiae. Mol. Cell. Biol. 11: 31053114

Tao, Y. and Chen, K. Y. (1995a) Purification of deoxyhypusine synthase from Neurospora crassa to homogeneity by sub- strate elution affinity chromatography. J. Biol. Chem. 270: 383386

Tao, Y. and Chen, K. Y. (1995b) Molecular cloning and functional expression of Neurospora deoxyhypusine synthase cDNA and identification of yeast deoxyhypusine synthase cDNA. J. Biol. Chem. 270: 23984-23987

Tao, Y. and Chen, K. Y. (1996) Molecular cloning and functional expression of human deoxyhypusine synthase cDNA based on expressed sequence tag information. Biochem. J. 315: $429-434$

Wöhl, T. (1993) The HYP2 gene of Saccharomyces cerevisiae is essential for aerobic growth: characterization of different isoforms of the hypusine-containing protein Hyp2p and analysis of gene disruption mutants. Mol. Gen. Genet. 241: 305-311

Wolff, E .C., Park, M. H. and Folk, J. E. (1990) Cleavage of spermidine as the first step in deoxyhypusine synthesis. J. Biol. Chem. 265: 4793-4799

Wolff, E. C., Lee, Y. B., Chung, S. I., Folk, J. E. and Park, M. H. (1995) Deoxyhypusine synthase from rat testis: purification and characterization. J. Biol. Chem. 270: 8660-8666

Zhang, G., Kazanietz, M. G., Blumberg, P. M. and Hurley, J. H. (1995) Crystal structure of the cys2 activator-binding domain of protein kinase $\mathrm{C}$ delta in complex with phorbol ester. Cell 81: 917-924 